\title{
Comparing the self-control and behavioral problems of girls in employed and unemployed mothers
}

\author{
Fahimeh Babanezhad
}

Corresponding author, Department of psychology , Islamic Azad University Central Tehran Branch.

E-mail address: h.farzaneh13932014@gmail.com

Keywords: self control Behavioral disorders, Mothers, Employment

\begin{abstract}
This research aims to compare styles of self-control and behavioral problems of girls in employed and unemployed mothers. In this research that was done using casual-comparison method (after events) 100 employed mothers and 100 unemployed ones of girls of elementary schools in district 4 of Tehran were selected as the sample based on cluster-random method. Selfcontrol questionnaire (Allahverdipour et al., 2005) and children's behavioral problem questionnaire (parental form, 1994) were used for information collection that was previously normalized in studies conducted in Iran and its validity has been confirmed. In this research, reliability of the questionnaire was assessed through Cronbach alpha and was confirmed with a high reliability of 0.80. The t-test was used to test the hypotheses. The results showed that the average of self-control in employed mothers is significantly more than that in unemployed mothers. Also, the results showed that there is a statistically significant difference between girls of employed and unemployed women in hyperactivity and aggression, anxiety and depression, disorder, and lack of attention. This research confirms that employment of women results in enhancement of behavioral disorder among children. It is suggested that policy makers and planners in the country must pay attention to this point.
\end{abstract}

\section{INTRODUCTION}

Family is the first founder of the personality, values and child's intellectual criteria. Mutual interactions between parents and children are considered as the basis of children's emotional change and this mutual interaction at all stages of his/her life, shows own self. Among the most important steps is childhood that is a stressful stage for parents and children and the effects of parents during this stage and development of its normal changes are very important (Driscoll et al., 2008). Studies have shown that behavioral problems are of the most common problem that children and adolescents associated with it (Halahan and Kafman, 2008). On the other hand, if some problems such as lack of attention, hyperactivity, behavioral disorder, comprehensive anxiety, depression, disobedience, fear, and etc that can be occurred in the form of beating, fight, yelling and screaming, sabotage, threat, escape from school, educational failure, and delinquency are not be paid attention, can result in behavioral problems (Halahan and Kafman, 2008). The studies have shown that behaviors such as seclusion and physical complaints are also behavioral disorders that after the second year of the school have gradually increased and it reaches considerable and worrying level in fifth and sixth years. Indeed, when a child achieves cognitive ability he/she will be able to remember and predict negative and stressful events and imagine them (Fanti, 2007). Many factors such as parenting (Farzadfar and Hooman, 2007), anxiety and mother depression (Mohammadzadeh and Najafi, 2010), exciting atmosphere and matrimony satisfaction (Soltanifar and Bina, 2007), factors related to school and attitude of teachers (Fortin et al., 2010), understood family relations by children, mutual and dynamic interactions among persons, multiple levels of environment and supportive relations of family members (Lubenko and Sebre, 2010) are effective on creating children behavioral problems. Also, according to determined studies, each of children behavioral problems can underlie the other problems and occur in various forms in adulthood. Based on the results of researches, it has been determined that self-control (self-regulatory) is one of the most skills as the characteristic of capable people in life. Self-control refers to psychological properties related to control and the personal supervision on the behavior and indicates that the person is able 
to postpone his/her behavior and again conducts it in a clear and goal-oriented way. Based on Guf's definition (1975) the lower level of this property in the person causes a behavior based on impulsivity and pleasure-seeking and the person can difficultly postpone his/her impulsivity. A considerable part of adult psychological pathology is related to self-control (Alizadeh, 2005). Since interpersonal conflicts are in a close relation with excitements, hence firstly the excitements should be recognized for controlling conflicts and then control them. So in this case, people must have both self-awareness and self-control properties. People who do not have these properties can earn more knowledge about the conflicts and in this way recognize the conflicts more quickly and correctly and conduct it with more confidence. And therefore, provide an environment in where people obtain more performance and psychological health by knowing personal values and can select a proper conflict style for each situation (Etebarian and Pourvali, 2008). Some people are sensitive to social situations and set their appearance appropriate to the common situation. These people are named "high self-control people" and against there are some ones with lower self-control who tend to state their thoughts and feelings to organize them in accordance with the situation. Also, self-control is defined as an important personal and measurable difference of behavioral properties indicating the consistency of behavioral properties with available situations and status (Kritner and Kiniki, 2005). Today, women employment especially in Tehran has had a growing trend so that many women spend less time at home. Nevertheless, despite importance of job and family, limited studies have been conducted in the form of attention to interactions between job and family (Godarzi et al., 2010). This research aims to compare self-control styles and behavioral problems in employed and unemployed mothers and answers these questions that can employment of women due to restricted presence at home effective on children behavioral problems? And has employment resulted in difference in women self-control styles?

\section{Research model}

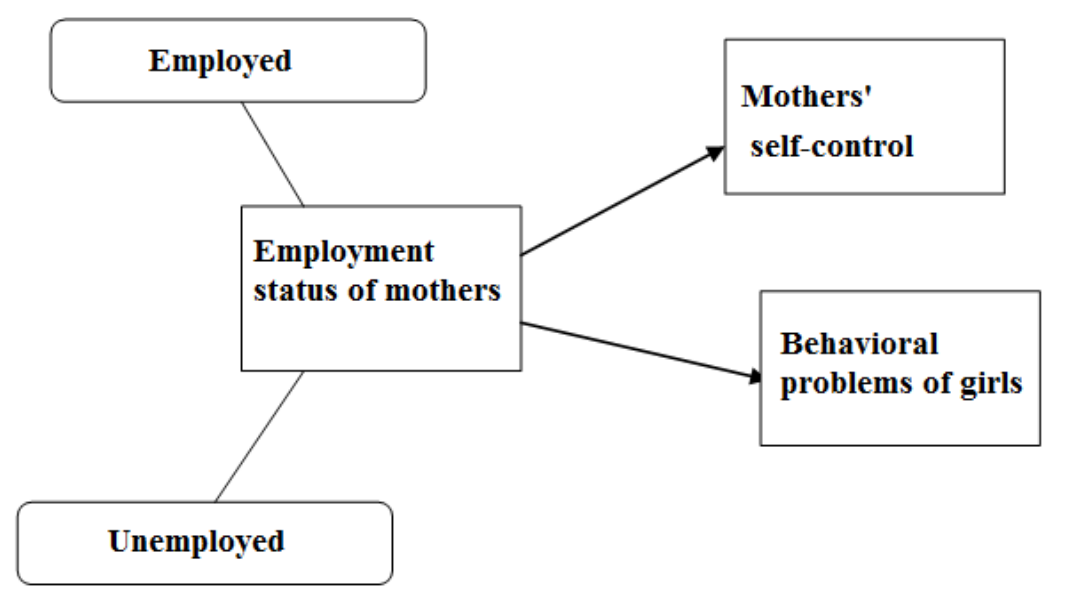

\section{METHOD}

The present study is of a comparative-casual or after event type. Statistical population in this research was the mothers of elementary school girls in district 4 of Tehran. 100 employed mothers and 100 unemployed ones in district 4 of Tehran were selected using cluster-random method. The most important data collection tool in this research was self-control questionnaire (Allahverdipour et al., 2005) and children's behavioral problem questionnaire (parental form, 1994).

\section{Allahverdipour and colleagues' self-control questionnaire (2005)}

This questionnaire is a questionnaire with 12 questions that measures personal self-skillfulness. A score of 1 to 5 is given for answering each question (at all $=0$ to very high $=5$ ) that is the minimum and maximum score are 0 and 6, respectively. This questionnaire was normalized and confirmed by Allahverdipour et al. for first time and its reliability was calculated using internal coordination 
method (Cronbach alpha) 0.80. Also, in this research, the reliability was obtained at 0.772 using Cronbach alpha indicating acceptable reliability of the questionnaire.

\section{Children's behavioral problem questionnaire (parental form, 1994)}

This questionnaire includes 31 items and issues related to health and children habits. Scoring in this questionnaire is in a three-scale form including: true $=0$; partly true $=1$; and completely true $=2$. Rother (1994) did a wide study about 10- and 11-year old children. In this study, 1536 children were investigated using Rother's questionnaire and also the reliability of this questionnaire was assessed. Rother reported reliability of retest and questionnaire 0.74 in a pretest-posttest study within two months. In Iran also reported reliability of correlation parental form 0.74 in a pretestposttest study within two months.(quoted by Bardideh et al., 2010). Sine this questionnaire is standard, there is no need to investigate its validity again in this research and only its reliability was calculated using Cronbach alpha after completion of 30 questionnaires by research samples. The reliability for hyperactivity and aggression, anxiety and depression, social incompatibility, antisocial behaviors, and attention deficit disorder was obtained $0.83,0.86,0.80,0.84$, and 0.82 , respectively indicating an acceptable reliability of the research questionnaire. Also, SPSS software and t-test were used to analyze data and to test hypotheses, respectively.

\section{Findings}

In this research, 100 employed mothers and 100 unemployed ones in district 4 of Tehran were studied. The average of self-control in employed and unemployed women was 35.81 and 28.84, respectively. For unemployed women, the average of styles of integration conflict resolutions, required conflict resolution, the dominant conflict resolution, avoiding conflict resolution, and reconciliation conflict resolution was obtained 29.92, 26.08, 16.44, 15.48, and 15.88, respectively. The average of behavioral disorder of employed women girls in hyperactivity and aggression, anxiety and depression, social incompatibility, anti-social behaviors, and attention deficit disorder was obtained 2.68, 1.87, 1.83, 1.89, and 2.20, respectively. The average of behavioral disorder of unemployed women girls in hyperactivity and aggression, anxiety and depression, social incompatibility, anti-social behaviors, and attention deficit disorder was obtained 1.90, 1.72, 1.81, 1.80 , and 1.80 , respectively.

\section{Hypothesis 1: self-control is different among employed and unemployed mothers in Tehran.}

This hypothesis has been tested using t-test and the results are given in Tables 1 and 2.

Table 1. Investigating the difference of average of self-control between employed and unemployed women

\begin{tabular}{|c|c|c|c|c|c|c|c|c|c|}
\hline \multicolumn{6}{|c|}{ t-test of equality of averages } & \multicolumn{2}{|c|}{$\begin{array}{c}\text { Levene's test of } \\
\text { equality of variances }\end{array}$} & & \\
\hline \multicolumn{2}{|c|}{$\begin{array}{c}\text { Confidence } \\
\text { interval of } 95 \%\end{array}$} & \multirow[t]{2}{*}{$\begin{array}{l}\text { Average } \\
\text { Difference }\end{array}$} & \multirow[t]{2}{*}{$\begin{array}{c}\text { Significance } \\
\text { level }\end{array}$} & \multirow{2}{*}{$\begin{array}{l}\text { Degree } \\
\text { of } \\
\text { freedom }\end{array}$} & \multirow[t]{2}{*}{$\mathrm{t}$} & \multirow[t]{2}{*}{$\begin{array}{c}\text { Significance } \\
\text { level }\end{array}$} & \multirow[t]{2}{*}{$\mathrm{F}$} & & \\
\hline $\begin{array}{l}\text { Upper } \\
\text { limit }\end{array}$ & $\begin{array}{l}\text { Lower } \\
\text { limit }\end{array}$ & & & & & & & & \\
\hline 35.8100 & 100 & 6.97000 & 0.000 & 198 & 8.924 & 0.803 & 0.063 & $\begin{array}{l}\text { Variances } \\
\text { are equal }\end{array}$ & Self-control \\
\hline 28.8400 & 100 & 6.97000 & 0.000 & 197.998 & 8.924 & & & $\begin{array}{l}\text { Variances } \\
\text { aren't equal }\end{array}$ & \\
\hline
\end{tabular}

As can be seen in Table 1, the significance level of t-test is lower than 0.05. Consequently, initial hypothesis is rejected at level of 0.05 . Therefore, there is a statistically significant difference in selfcontrol between employed and unemployed women.

Table 2. Average and standard deviation of self-control

\begin{tabular}{|c|c|c|c|c|}
\hline Standard deviation & Average & Number & & \\
\hline 5.51343 & 35.8100 & 100 & Employed women & \\
\hline 3.53176 & 28.8400 & 100 & Unemployed women & \\
\hline
\end{tabular}


The average and standard deviation of self-control have been given in employed and unemployed women.

The average of self-control in employed and unemployed women is 35.81 and 28.84, respectively.

\section{Hypothesis 2: The extent of behavioral problems is different among girls of employed and unemployed mothers in Tehran.}

This hypothesis has been tested using t-test and the results are given in Tables 3 and 4.

Table 3. Investigating the difference of average of behavioral disorders in girls with employed and unemployed women

\begin{tabular}{|c|c|c|c|c|c|c|c|c|c|}
\hline \multicolumn{6}{|c|}{ t-test of equality of averages } & \multicolumn{2}{|c|}{$\begin{array}{c}\text { Levene's test of equality of } \\
\text { variances }\end{array}$} & & \\
\hline \multicolumn{2}{|c|}{$\begin{array}{l}\text { Confidence interval } \\
\text { of } 95 \%\end{array}$} & \multirow[t]{2}{*}{$\begin{array}{c}\text { Average } \\
\text { Difference }\end{array}$} & \multirow[t]{2}{*}{$\begin{array}{c}\text { Significance } \\
\text { level }\end{array}$} & \multirow{2}{*}{$\begin{array}{l}\text { Degree } \\
\text { of } \\
\text { freedom }\end{array}$} & \multirow[t]{2}{*}{$\mathrm{t}$} & \multirow[t]{2}{*}{$\begin{array}{c}\text { Significance } \\
\text { level }\end{array}$} & \multirow[t]{2}{*}{$\mathrm{F}$} & & \\
\hline $\begin{array}{l}\text { Upper } \\
\text { limit }\end{array}$ & $\begin{array}{c}\text { Lower } \\
\text { limit }\end{array}$ & & & & & & & & \\
\hline 1.808 & 0.128 & 0.780 & 0.048 & 98 & 1.722 & \multirow[t]{2}{*}{0.020} & \multirow[t]{2}{*}{10.220} & $\begin{array}{l}\text { Variances } \\
\text { are equal }\end{array}$ & \multirow[t]{2}{*}{ Integration } \\
\hline 1.808 & 0.128 & 0.780 & 0.048 & $\begin{array}{l}97.48 \\
\end{array}$ & 1.722 & & & $\begin{array}{l}\text { Variances } \\
\text { aren't equal }\end{array}$ & \\
\hline 1.132 & 0.708 & 0.15 & 0.000 & 98 & 4.701 & \multirow[t]{2}{*}{0.001} & \multirow[t]{2}{*}{10.917} & $\begin{array}{l}\text { Variances } \\
\text { are equal }\end{array}$ & \multirow[t]{2}{*}{ Dominant } \\
\hline 1.132 & 0.708 & 0.15 & 0.000 & 77.80 & 4.701 & & & $\begin{array}{c}\text { Variances } \\
\text { aren't equal }\end{array}$ & \\
\hline 1,125 & 0.715 & 0.05 & 0.129 & 94 & 4.701 & \multirow[t]{2}{*}{0.121} & \multirow[t]{2}{*}{11.801} & $\begin{array}{c}\text { Variances } \\
\text { are equal }\end{array}$ & \multirow[t]{2}{*}{ Required } \\
\hline 1.125 & 0.715 & 0.05 & 0.129 & 81.50 & 4.701 & & & $\begin{array}{l}\text { Variances } \\
\text { aren't equal }\end{array}$ & \\
\hline 1.081 & 0.814 & 0.09 & 0.128 & 92 & 2.401 & \multirow[t]{2}{*}{0.121} & \multirow[t]{2}{*}{11.427} & $\begin{array}{l}\text { Variances } \\
\text { are equal }\end{array}$ & \multirow[t]{2}{*}{ Avoiding } \\
\hline 1.081 & 0.814 & 0.09 & 0.128 & 80.11 & 2.401 & & & $\begin{array}{l}\text { Variances } \\
\text { aren't equal }\end{array}$ & \\
\hline 1.002 & 0.808 & 0.4 & 0.000 & 95 & 4.701 & \multirow[t]{2}{*}{0.001} & \multirow[t]{2}{*}{9.823} & $\begin{array}{l}\text { Variances } \\
\text { are equal }\end{array}$ & \multirow[t]{2}{*}{ Reconciliation } \\
\hline 1.002 & 0.808 & 0.4 & 0.000 & 77.22 & 4.701 & & & $\begin{array}{l}\text { Variances } \\
\text { aren't equal }\end{array}$ & \\
\hline
\end{tabular}

According to Table 3, the significance of t-test in all behavioral disorders of girls except social Incompatibility and anti-social behaviors is lower than 0.05 and thus there is a statistically significance difference in behavioral disorders (hyperactivity and aggression, anxiety and depression, social incompatibility, and attention deficit disorder) of girls of employed and unemployed mothers.

Table 4. Average and standard deviation of behavioral disorders in girls in terms of employment status of the

\begin{tabular}{|c|c|c|c|c|}
\multicolumn{9}{|c|}{ mother } \\
\hline Standard deviation & Average & Number & \multicolumn{1}{c|}{$\begin{array}{c}\text { Hyperactivity and } \\
\text { aggression }\end{array}$} \\
\hline 1.02 & 2.68 & 100 & Employed women & Anxiety and depression \\
\hline 1.01 & 1.90 & 100 & Unemployed women & \\
\hline 1.42 & 1.87 & 100 & Employed women & Social incompatibility \\
\hline 1.12 & 1.72 & 100 & Unemployed women & \\
\hline 1.32 & 1.83 & 100 & Employed women & \multirow{2}{*}{ Anti-social behaviors } \\
\hline 1.20 & 1.81 & 100 & Unemployed women & \\
\hline 1.32 & 1.89 & 100 & Employed women & \\
\hline 1.12 & 1.80 & 100 & Unemployed women & \\
\hline 1.32 & 2.20 & 100 & Employed women & attention deficit disorder \\
\hline
\end{tabular}

As can be observed in Table 4, the average hyperactivity and aggression in girls with employed women is more than that of the girls with unemployed women. The average anxiety and depression in girls with employed women is more than that of the girls with unemployed women. The average attention deficit disorder in girls with employed women is more than that of the girls with unemployed women. 


\section{DISCUSSION AND CONCLUSIONS}

The results of the present study showed that the average of self-control in employed women is more than that of the unemployed women and it seems employed women have learnt the skills of self-control better than unemployed women that this point can be resulted from their more presence in the society due to their employment and this can lead to face with more opportunities in the society and learn skills to use them in their life. This is due to both the management of excitements and feelings of employed women resulted from their more presence in the society and facing with various opportunities and utilizing the others' experiences due to more communications with the others. The results showed that hyperactivity and aggression of girls with employed mothers are more than that of the girls with unemployed mothers. Attention deficit disorder in girls with employed women is more than that of the girls with unemployed women. This can be resulted from the fact that employed mothers due to their employment in the society, allocate less time for their family and children with respect to unemployed mothers and this causes children may be more likely to interfere with attention deficit disorder. Sometimes, due to high pressure of work, employed women experience more stress and anxiety that this stress and anxiety are transferred into the home environment and finally children. Sometimes, employed mothers' impatience can result in less attention to children and finally their depression. Previously, research has shown that domineering methods are determined by threatening orientation. In accompaniment method, information exchange and investigating differences are to achieve an acceptable solution for both sides. This method is in relation with problem solving and it can result in creative problem solving (Sorenson, 1999). Also, studies have shown that required conflict resolution style or kind method indicates attempts for decreasing differences and emphasizes similarities for achieving expectations and the others' issues. The reconciliation method is located in middle point of attention to expectations and needs of others and refers to division of scores among both sides (Sorenson, 1999). The results of studies have shown that avoiding method is in relation with seclusion opportunities, giving responsibility to others, incriminating others, and receding own self (Sorenson, 1999). In families where the shapes of social behaviors are improper, inconsistent children are grown up. And even if these children can show consistency to some extent outside of the house and among their friends, they will probably have inconsistency in many social activities (Yavouzar, 2003). Finally, avoiding style is determined with properties such as evading, behaving passively or not acting, and dependence (Dezorila et al., 2011). In this field, studies have shown that training the skills of communications to couples leads to mental health improvement (Askari et al., 2013). Improving their mental health is accompanied by better training of children and the latter is accompanied by less behavioral problems and disorders. Findings of the present study determine the necessity of preventive programs and therapeutic interventions for children in families with employed mothers. However, treatment of behavioral disorders is very important, but the necessity of preventive programs for preventing the occurrence of behavioral disorders is more vital. Preventive programs can be focused in four aspects of training children, family, school, and society (planners and authorities). Undoubtedly, helping children with behavioral disorders is necessary because the continuation of behavioral disorders within life with the onset of childhood determine the importance of early intervention not only for decreasing suffering of children and adolescents but also for preventing a wide range of psychological problems in adulthood. 


\section{References}

[1] Babapour, Kheir Aldin, J. (2006), investigating the relationship between conflict resolution practices of communication and psychological health of students, Scientific-Research Journal of Psychology, University of Tabriz, 4, pp. 27-46.

[2] Beverly J. W. Holly P., Jenna Y., Kathleen K., Jessica B., Lindsey K.\& Diana C.(2014), Parental Emotion Coaching: Associations With Self-Regulation in Aggressive/Rejected and Low Aggressive/Popular Children, Child \& Family Behavior Therapy. Vol 36, Issue 2, p.p.: 81-106.

[3] Byrne BA, Haddock CK, \& Poston DC, (2002). Mid American Heart Institiute: Parenting style and adolescent smoking. Journal of Adolescent Health, (30)6, 418-425.

[4] Duman, S. \& Margolin, G. (2007). Parents' Aggressive Influences and Children's Aggressive Problem Solutions With Peers. Journal of Clinical Child and Adolescent Psychology, 36(1), $42-55$

[5] Dustin A. Pardini, Rebecca Waller, Samuel W. Hawes(2015),Familial Influences on the Development of Serious Conduct Problems and Delinquency, The Development of Criminal and Antisocial Behavior,p.p. 201-220.

[6] Etebarian, Akbar, Pourvali, Zeinab, (2008), determining the relationship between self-control and conflict resolution strategies among administrative staff of Khorasgan Azad University (Isfahan), New approach in educational management, 1(2) pp. 113-133.

[7] Fanti, k.a. (2007), trajectories of pure and co-occurring internalizing and externalizing problems from age2to12: findings fromthenichd.study of the requirements for $\mathrm{PhD}$ degree. Georgiastste University.

[8] Farzadfar, Z., Homan, H., (2008), the role of the role of parenting skills on reducing maternal stress in mothers and behavioral problems in children, Journal of Iranian psychologists, 4 (15), pp. 277-292.

[9] Fortin, L;lessard, A;\&marcotte, D.(2010),Comparison by gender of students with behavior problems who dropped out of school. Journal of social and behavioral sciences. , 2.

[10] Goudarzi, Z., Bakhti, O., Yousefi, F., Shamshiri, A., Mahmoudi Gharaei, J., Atef Vahid, M., Voskouei Ashkouri, K., Abbasi Marei, F., Etaati, Z., (2010), investigating the relation shift work with abilities and behavioral problems in 7 to 12 year old-children of employed parents with shift work, Research and Nursing, 5 (18), pp. 42-50.

[11] Hallahan, de , Kauffman, J, (1944), Exceptional Children: An introduction to special education, translated by Mojtaba Javadian, (2008), Mashhad: Astan_e_Qods_e_Razavi Press.

[12] Khazaei, T., Khazaei, M.M., Khazaei, M., (2005), the prevalence of behavioral problems in Birjand children, Birjand University of Medical Science Journal, 12 (1\&2), pp.71-96.

[13] Kumru Asiye, Thompson, Ross A.(2003). "Ego Identity Status and Self Monitoring Behavior in Adolescents", Journal of Adolescen t Research, Vol. 18 No.5, pp , 481-495.

[14] Lubenko, J; \& sebre, S (2010), Longitudinal associations between adolescent behavior problems and perceived family relationships. Journal of procedia social and behavior sciences.5. 
[15] Mohammadzadeh, A., Najafi, M., (2010), the role of anxiety and depression in determining attention deficit disorders in elementary school children, Clinical Psychology Journal, 1 (4), pp. 59-66.

[16] Rahim, A, Kaufman, S \& Psennica, C. (2004). A Model of the style of Handling conflict, Marital satisfaction, and Instability. Available online at: http://papers.ssrn.com/sol3/ Data Integrity_Notice.cfm?abid $=602765$

[17] Soltanifar, A., Bina, M., (2007), investigating the prevalence of depression symptoms in elementary school 9-11 year old-children in Tehran and its relation with family function, Journal of Mental Health Principles, 9 (33\&34), pp. 7-14.

[18] Stefan, C; \&Miclea, M.(2010), Prevention program for children with emotional and social competencies. Journal of prcedia social and behavioral sciences, 5, p.p.:127-139.

[19] Tate,Brian(2008). "A Longitudinal Study of the Relationships Among Self - Monitoring, Authentic Leadership, and Perception of Leadership . Journal of Leadership \& Organizational Studies. Vol15, n1, p.p.: 16-29. 